\title{
Tourist Satisfaction and Destination Loyalty: A Case study of the World Heritage Site of Ellora Caves
}

Sonali Tirath Gaikwad*, Rajesh Ragde` and Madhuri Sawant ${ }^{\ddagger}$

\section{Abstract}

The willingness of Tourists to revisit a destination is strongly influenced by tourist satisfaction which plays a vital role in improving destination loyalty. The present research aims to study destination loyalty of the tourists based on their satisfaction at the world heritage site of Ellora caves in India.The sampling group of the study consisted of 60 tourists who visited Ellora Caves in July 2019. Pearson correlation analysis was applied for data analysis. The study concluded that there was a positive and strong affiliation between tourist satisfaction and destination loyalty. Constructive suggestions like adherence of strict rules \& regulations and quality training programmes for service providers were given to improve tourist's delight at Ellora Caves. The suggestions given are applicable for destination planners, and tourism authorities for future revisits.

Keywords: Destination Loyalty, Perception, Tourist Satisfaction, Ellora Caves.

\section{Introduction}

Ellora Caves is one of the largest rock cut monastery caves temples in the world and a UNESCO world heritage site in Aurangabad district of

\footnotetext{
* RGNF-SRF; Dr. Babasaheb Ambedkar Marathwada University (DBAMU), Aurangabad, Maharashtra, India; t.sonali.gaikwad@gmail.com

† Director, Department of Tourism Administration (DBAMU), Aurangabad, Maharashtra, India; drrajeshtourism@gmail.com

‡ Director, ICBT, Department of Tourism Administration (DBAMU), Aurangabad, Maharashtra, India; drmadhurisawant@gmail.com
} 
Maharashtra, India. The site presents monuments and artwork of Buddhism (caves 1-12), Hinduism (caves 13-29) and Jainism (caves 3034) from 600 to $1000 \mathrm{CE}$ period. The most visited Kailasha cave temple (cave 16) is considered to be one of the most outstanding cave temples in India because of its size, architectural beauty and having been wholly carved out of a single rock. The site features 34 caves which are open to visit for tourists and over 66 unfinished caves.

People travel from one place to another to fulfil initial needs. It is crucial to understand tourist satisfaction, especially for enhancing tourism business economy, by attracting tourists in the future. The positive experiences tourists have at a tourism destination will not only enhance their intent to revisit the destination, but also ensure that they will give positive review about the destination to their friends and/or relatives. The travel, from the time of leaving home till returning, consists of a series of attributes, including infrastructural aspects, activity amenities, transportation, accommodation, restaurants, appealing monument, overall tourist satisfaction at the destination, service level in general, specific activities, shopping, etc. After the visit of tourists all these attributes are viewed as possible influences on overall satisfaction at the destination and later on the intention to revisit and communicate via positive word of mouth. Therefore,tour planners, managers, and experts need to understand what makes tourists loyal to a destination and what their expectations are so that destinations can modify their offerings, service delivery and communication strategies to meet and exceed tourists'expectations. Though a lot of work has been done on the world heritage site of Ellora caves, no systematic attempt has been made to study tourist satisfaction and destination loyalty. Hence, the present research aimed to study destination loyalty of the tourists based on their satisfaction at the world heritage site of Ellora caves.

\section{Review of Literature}

\subsection{Tourist Satisfaction}

Ibrahim \& Gill (2005) stated that in a competitive market economy, much attention had been given to the concept of consumer satisfaction measurement (cited in Hassan \&Shahnewaz, 2014) since success in business is clearly determined by customer satisfaction and thereby 
achieving loyalty. Satisfaction is considered as one of the most critical determinants of loyalty because of its significant impact on the destination selection, the selection of activities and services, the future visitation intentions and the decision to recommend to others. Therefore tourist's satisfaction with each attribute and its importance should be assessed to measure overall satisfaction. These studies concluded that it could lead to positive behavioural reactions from tourists, such as repeat visits and positive WOM (Gursoy et al., 2014).

The study of customer satisfaction in tourism began in the 1960s (Wang, Zhang, Gu, \& Zhen, 2009). The literal meaning of satisfaction is vague because there is no universal scale to estimate consumer satisfaction (Rahman \& Shil, 2012). Satisfaction/dissatisfaction is derived from tourist's experience with the tourist destination (Mohamad, Ali, et al., 2011). Nowacki (2013) elaborated that satisfaction is the reason why people visit various destinations. It is a determinant of the quality of visit as well as of attraction, that is, the performance of attraction providers in terms of providing service to their visitors. Service providers like tourist guides and host communities play a vital role in overall tourist experience (Ragde, 2014a, 2014b). The significant indicators of visitor satisfaction include experiences from the visit and visitors' behavioural intentions towards attractions. Kumar \& Dar (2017) added that tourist satisfaction isvitalfor destination success. Satisfied tourists are the brand ambassadors of a particular tourist destination which uses "word of mouth" method and recommend it to others.

Nowadays it is one of the most important concerns of competitive destinations which ensures the future of the destination as it considerably influences the tourist's choice of a destination, the consumption of products and services and the decision to revisit the destination in the future or recommend it to others(M. A. Bhat \& Qadir, 2013; Gnanapala, 2016; Huh et al., 2006; Kozak \& Remmington, 2000; Shirazi \& Som, 2013; Somaskanthan \& Rosmalina, 2016).

Dmitrovic et al. (2009) mentioned that enhancing customer satisfaction should be one of a DMO's primary functions and a prerequisite for the strategy development leading to a destination's enhanced attractiveness and its competitive positioning. Moreover, they added that monitoring of tourist satisfaction is a continuous process which provides inputs for trend analysis and strategic decision making. The 
major indicators of the satisfaction are behavioural intentions: revisit intentions, word-of-mouth and willingness to pay. The main factors influencing satisfaction include motivations, experiences from the visit, benefits and education (Nowacki, 2013). Thus tourist satisfaction plays a significant role in attracting repeat visitors (Destination loyalty).

Further Yoon \& Usyal (2005) expressed that a positive word of mouth is not only an indicator of a tourist's intention to continue the relationship with the destination, but also a reliable source of information for potential tourists. To conclude, satisfied tourists will not only revisit the destination but also provide positive reviews and recommend it to others.

\subsection{Destination Loyalty}

Studies suggested that there is a close relationship between previous experiences, consumer satisfaction and loyalty; as repeat visitors were more likely to be satisfied with their travel experiences and were more likely to return and spread positive word-of-mouth (Chi, 2012). Mohamad, Ali, et al., (2011) and Mohamad, Abdullah, \& Mokhlis (2011) used the terms customer loyalty or destination loyalty alternatively and described it as the behavioural intention to revisit and disseminate the positive word of mouth about a particular destination to others. Opermann (2000) stated that tourist intention to revisit the destination or recommend to others is mostly determined by the extent of loyalty (cited in Hassan \& Shahnewaz, 2014).

In this manner,Guntoro\& Hui (2013) highlighted that many destination areas had to rely heavily on repeat visitation. They also identified five reasons why people undertake repeat visits: risk reduction/ contentment with a particular destination, find the same kind of people, emotional attachment to a place, further exploration of a destination, and show the destination to other people cited in Gitelson and Crompton (1984).

\subsection{Relation between Tourist Satisfaction and Destination Loyalty}

Earlier Research studies have proven that there is a relation between satisfaction and loyalty. Satisfaction is found to directly affect destination loyalty in a positive direction (Yoon \& Usyal, 2005). It is stated that if the tourists are satisfied with the exact needs, it will lead them towards forming loyal tourists base for the destination i.e. higher 
the customer satisfaction, higher the loyalty (Gnanapala, 2016; Hikmah et al., 2018; Ibrahim \& Gill, 2005).

Mohamad \& Izzati (2014) examined the relationship of tourist satisfaction toward destination loyalty by conducting a survey of 261 European tourists. The finding of the study found that tourist satisfaction had a direct positive influence on destination loyalty. The study also found that tourists with a high level of satisfaction are willing to recommend the destination and spread positive word-ofmouth to other people.

Another important research was done on repeat visit intention on 192 Chinese tourists at Singapore airport using one-way analysis of variance. The results revealed that safety was still the most crucial attribute why the Chinese tourists had the intention to revisit Singapore (Guntoro\& Hui, 2013).

In Indian context, it was observed that many research studies on destination satisfaction and loyalty were performed on the north Indian tourist destinations like Jammu \& Kashmir, Ladakh, Gujarat etc.One crucial study conducted by S. A. Bhat \& Darzi (2018)at the sample area of Jammu, Kashmir and Ladakh found that there is a significant relationship between destination image, tourist satisfaction and destination loyalty. Through this extensive review of literature, it was observed that destination loyalty would not be achieved unless the tourists feel satisfied at the destination.

Hence it is necessary to measure tourist satisfaction with the destination. In regards to Maharashtra state, it was observed that though it is a leading tourism state in the country, very limited research has been done in the area of destination loyalty. Further, it was found that no systematic attempt has been made to study the satisfaction of tourists visiting the World Heritage Site of Ellora caves. Thus this is a sincere attempt to fill the research gap by studying destination loyalty of the tourists visiting Ellora caves based on their satisfaction. The hypothesis for the study is there is no relationship between tourist satisfaction and destination loyalty at Ellora caves. 


\section{Research Methodology}

Primary data was collected from 60 tourists who visited Ellora Caves in July 2019. Secondary data was also collected from books, research journals, magazines, newspapers, MTDC website. A questionnaire was used as a Research Tool to collect primary data from the respondents visiting Elloracaves. The first section of the questionnaire included 32 attributes of tourist satisfaction, the second section included destination loyalty measuring 5 attributes, and the third part included demographic profile of the respondents at the destination. Each item in the scale was subjected to a 5point Likert scale (Poor=1, Unsatisfactory=2, Can't say=3, Good=4, Excellent=5) for measuring tourist satisfaction. Destination loyalty was also measured by using 5 point Likert scale (Strongly Disagree=1, Disagree=2, Can't say=3, Agree=4, Strongly Agree=5). The face validity of the construct was tested with the help of tourism experts and tourism researchers. They were asked for their opinions on satisfaction, and loyalty attributes and accordingly some of them were replaced. For few of them proper explanation was given and thus face validity of the construct was deemed satisfactory.

Additionally, Cronbach's Alpha test was used to test reliability. For this 30 responses of tourists were collected from the pilot survey at Elloracaves in Aurangabad. The result of Cronbach's Alpha test produced the value of 0.968 (>.7) for satisfaction attributes \& 0.891 (>.7) for loyalty attributes which indicated strong reliability of the scale for both.

Table 1: List of attributes and their sources:

\begin{tabular}{llll}
\hline $\begin{array}{l}\text { Sr. } \\
\text { No }\end{array}$ & \multicolumn{1}{c}{ Factors } & \multicolumn{1}{c}{ Attributes } & \multicolumn{1}{c}{ Sources } \\
\hline 1. & About & Highly Appealing & (Jayaprakash \& Mythili, \\
& Ellora & Monument, Scenic & 2017); (Wu \& Zheng, \\
& Caves & Beauty around the & 2014);(Naidoo, 2010); \\
& & Ellora Caves, Shopping, & (Rajesh, 2013);discussion \\
& & Conservation of & with tourism expert. \\
& Heritage Sites under & \\
& ASI, Architectural & \\
& Beauty, Overall Tourist & \\
& Satisfaction at Ellora & \\
& Caves, Rate your \\
& experience about Ellora &
\end{tabular}




\section{Connectivity \\ 3. Civic \\ Administration \\ 4. Traffic \& Transport Management}

5. Types of facilities

6. Maintenance \& Management of the Destination
Caves visitor orientation centre.

Connectivity by Rail, Road, Flight.

Public Conveniences along roads, Cleanliness.

Traffic Management, Behavior of Taxi Driver/ Auto Driver, Availability of other commercial transportation, Behavior of other commercial transportations, Behavior of other commercial transportations. Availability of authorized Tour Operators, Availability of Luxury Hotels, Availability of Budget Hotels, Behavior of the staff of the service providers,

Affordability of accommodation facilities, Hygiene at wayside restaurants and Dhabas, Behavior of service personnel at wayside restaurants /Dhabas/Hotels. General cleanliness and beautification of monument \& area around it, public utilities, parking facilities, availability of tourist information centre, availability of
(Jayaprakash \& Mythili, 2017); (Wu \& Zheng, 2014); (Naidoo, 2010); (Tan et al., 2017); (Breiby \& Slåtten, 2018);

(Jayaprakash\& Mythili, 2017)

(Masarrat, 2012); (Yoon \& Usyal, 2005); (ZoghbiManrique-de-Lara \& Guerra-Báez, 2016); (Chandra \& Kala, n.d.).

(Masarrat, 2012);

(Jayaprakash \& Mythili, 2017); (M Philemon, 2015); (Rajesh, 2013); (Chandra \& Kala, n.d.); (Bernadette D'silva \& Stephen D'silva, n.d.); discussion with tourism experts.

Researchers observation; (Masarrat, 2012); (Athula Gnanapala, 2015); (Gnanapala, 2016); 


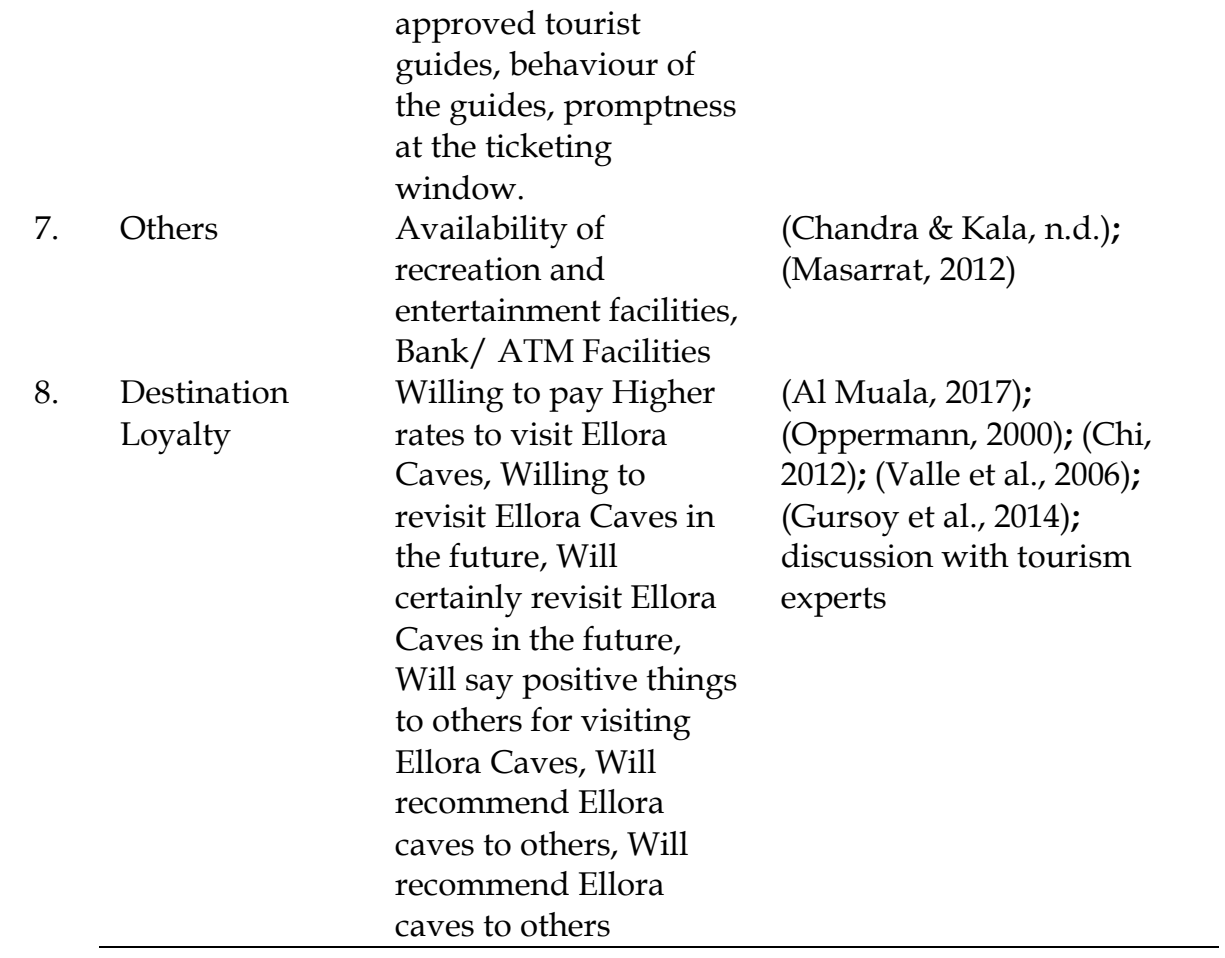

Data Analysis: Firstly,descriptivestatisticswereapplied to study the mean values of satisfaction of destination attributes (Table no.2). Secondly,Pearson correlation analysis was applied to study the relationship between Tourist Satisfaction \& Destination Loyalty using SPSS (Table no.4 \& 5).

Table 2: Mean values of satisfaction of destination attributes

\begin{tabular}{lrrrr}
\hline & Mean & $\begin{array}{c}\text { Std. } \\
\text { Deviation }\end{array}$ & Variance & Sum \\
\hline $\begin{array}{l}\text { Highly Appealing Monument } \\
\text { Scenic Beauty around the }\end{array}$ & 4.4833 & .77002 & .593 & 269.00 \\
$\begin{array}{l}\text { Ellora Caves } \\
\text { Shopping }\end{array}$ & 4.4833 & .59636 & .356 & 269.00 \\
$\begin{array}{l}\text { Conservation of Heritage Sites } \\
\text { under ASI }\end{array}$ & 2.5833 & 1.06232 & 1.129 & 155.00 \\
$\begin{array}{l}\text { Architectural Beauty } \\
\text { Overall Tourist Satisfaction at }\end{array}$ & 4.4500 & 1.33309 & 1.777 & 207.00 \\
$\begin{array}{l}\text { Ellora Caves } \\
\text { Rate your experience about }\end{array}$ & 4.3833 & .58488 & .342 & 263.00 \\
Ellora Caves visitor orientation & 4.2167 & .73857 & .545 & 253.00
\end{tabular}




\begin{tabular}{|c|c|c|c|c|}
\hline Connectivity by Rail & 2.3500 & 1.00549 & 1.011 & 141.00 \\
\hline Connectivity by Road & 2.8500 & 1.27326 & 1.621 & 171.00 \\
\hline Connectivity by Flight & 2.2000 & .83969 & .705 & 132.00 \\
\hline $\begin{array}{l}\text { Public Conveniences along } \\
\text { roads }\end{array}$ & 2.7167 & .92226 & .851 & 163.00 \\
\hline Cleanliness & 3.6000 & 1.15274 & 1.329 & 216.00 \\
\hline Traffic Management & 2.7833 & 1.05913 & 1.122 & 167.00 \\
\hline $\begin{array}{l}\text { Behaviour of Taxi Driver/ } \\
\text { Auto Driver }\end{array}$ & 2.8000 & 1.03825 & 1.078 & 168.00 \\
\hline $\begin{array}{l}\text { Availability of other } \\
\text { commercial transportation }\end{array}$ & 2.9167 & .97931 & .959 & 175.00 \\
\hline $\begin{array}{l}\text { Behaviour of other commercial } \\
\text { transportations }\end{array}$ & 2.9667 & .97366 & .948 & 178.00 \\
\hline $\begin{array}{l}\text { Availability of authorized Tour } \\
\text { Operators }\end{array}$ & 3.2500 & 1.06763 & 1.140 & 195.00 \\
\hline Availability of Luxury Hotels & 2.8833 & .97584 & .952 & 173.00 \\
\hline Availability of Budget Hotels & 2.9500 & 1.01556 & 1.031 & 177.00 \\
\hline $\begin{array}{l}\text { Behaviour of the staff of the } \\
\text { service providers }\end{array}$ & 2.9167 & .92593 & .857 & 175.00 \\
\hline $\begin{array}{l}\text { Affordability of } \\
\text { accommodation facilities }\end{array}$ & 2.9167 & 1.04625 & 1.095 & 175.00 \\
\hline $\begin{array}{l}\text { Hygiene at wayside restaurants } \\
\text { and Dhabas }\end{array}$ & 3.2833 & 1.13633 & 1.291 & 197.00 \\
\hline $\begin{array}{l}\text { Behaviour of service personnel } \\
\text { at wayside restaurants } \\
\text { /Dhabas/Hotels }\end{array}$ & 3.1500 & 1.11728 & 1.248 & 189.00 \\
\hline $\begin{array}{l}\text { General cleanliness and } \\
\text { beautification of monument \& } \\
\text { area around it }\end{array}$ & 3.7167 & 1.10610 & 1.223 & 223.00 \\
\hline Public Utilities & 3.0500 & 1.30741 & 1.709 & 183.00 \\
\hline Parking Facilities & 2.8167 & 1.26881 & 1.610 & 169.00 \\
\hline $\begin{array}{l}\text { Availability of Tourist } \\
\text { Information centre }\end{array}$ & 2.9000 & 1.13047 & 1.278 & 174.00 \\
\hline $\begin{array}{l}\text { Availability of approved } \\
\text { tourist guides }\end{array}$ & 3.3333 & 1.21665 & 1.480 & 200.00 \\
\hline Behaviour of the guides & 3.4667 & 1.18560 & 1.406 & 208.00 \\
\hline $\begin{array}{l}\text { Promptness at the ticketing } \\
\text { window }\end{array}$ & 2.6833 & 1.22808 & 1.508 & 161.00 \\
\hline $\begin{array}{l}\text { Availability of recreation and } \\
\text { entertainment facilities }\end{array}$ & 2.3167 & .99986 & 1.000 & 139.00 \\
\hline Bank/ ATM Facilities & 3.0000 & 1.37779 & 1.898 & 180.00 \\
\hline
\end{tabular}

Through analysis, it was observed that tourists were satisfied with the destination attributes like scenic beauty, architectural beauty, cave's 
visitor orientation centre, conservation of the monument. While tourists were dissatisfied about the infrastructural attributes like connectivity, public convenience, transport operators, budget hotels, public utilities, recreation and entertainment facilities, bank and ATM facilities. Overall tourist satisfaction achieved the mean value of 4.3833, which reflected the positive experience of the tourists.

Table 3: Destination Loyalty of tourists visiting Ellora Caves

\begin{tabular}{llllll}
\hline & $\begin{array}{c}\text { Willing to } \\
\text { pay Higher } \\
\text { rates to } \\
\text { visit Ellora } \\
\text { Caves }\end{array}$ & $\begin{array}{c}\text { Willing to } \\
\text { revisit } \\
\text { Ellora } \\
\text { Caves in } \\
\text { the future }\end{array}$ & $\begin{array}{c}\text { Will } \\
\text { certainly } \\
\text { revisit } \\
\text { Ellora } \\
\text { Caves in } \\
\text { the future }\end{array}$ & $\begin{array}{c}\text { Will say } \\
\text { positive } \\
\text { things to } \\
\text { others for } \\
\text { visiting } \\
\text { Ellora } \\
\text { Caves }\end{array}$ & $\begin{array}{c}\text { Will } \\
\text { recomme } \\
\text { nd Ellora } \\
\text { caves to } \\
\text { others }\end{array}$ \\
\hline$\quad$ Missing & 60 & 60 & 60 & 60 & 60 \\
Mean & 3.8167 & 4.1000 & 4.0167 & 4.2167 & 4.4000 \\
Std. & .92958 & .60226 & .67627 & .55515 & .52722 \\
Deviation & .864 & .363 & .457 & .308 & .278 \\
Variance & 229.00 & 246.00 & 241.00 & 253.00 & 264.00 \\
Sum & & & & & \\
\hline
\end{tabular}

Mean values of Destination loyalty attributes 4.4000 reflected that tourists were willing to revisit \& recommend the destination Table no.2.

Table 4: Mean Values of Destination loyalty \& tourist satisfaction

\begin{tabular}{llcl}
\hline & Mean & Std. Deviation & $\mathrm{N}$ \\
\hline Loyalty & 4.1100 & .55653 & 60 \\
Satisfaction & 3.1850 & .61990 & 60 \\
\hline
\end{tabular}

Table 4: Correlation between destination loyalty and tourist satisfaction

\begin{tabular}{cccc}
\hline & & loyalty & Satisfaction \\
\hline Loyalty & Pearson Correlation & 1 & $.494\left({ }^{* *}\right)$ \\
& Sig. (2-tailed) & & .000 \\
$\mathrm{~N}$ & 60 & 60 \\
Satisfaction & Pearson Correlation & $.494\left({ }^{* *}\right)$ & 1 \\
& Sig. (2-tailed) & .000 & \\
$\mathrm{~N}$ & 60 & 60 \\
\hline
\end{tabular}

** Correlation is significant at the 0.01 level (2-tailed). 
Correlation is a bivariate analysis that measures the strength of association between two variables and the direction of the relationship. In terms of the strength of the relationship, the value of the correlation coefficient varies between +1 and -1 . Table no. 4 shows that the value for Pearson's correlation coefficient $(\mathrm{r})$ between mean score of loyalty and mean score of satisfaction is 0.494 . The value of $r$ is statistically significant at the level of significance (0.01). We rejected the null hypothesis and accepted the alternate hypothesis that there is a statistical significant correlation between Tourist satisfaction and Destination Loyalty. Since this value is positive, we can conclude that there is a positive relationship between Tourist satisfaction and Destination Loyalty score.

\section{Conclusion \& Suggestions}

Considering that tourists are more of a mind to visit destinations they have never visited before. The results of the research indicated that there is a positive and strong affiliation between overall satisfaction and destination loyalty. Thus the study concluded that destination attributes are the most criticalindicator of total tourist satisfaction. Moreover, tourists were overwhelmed by the highly appealing monument, scenic beauty around Elloracaves, architectural beauty and overall tourist satisfaction at Ellora caves.

However, the lowest level of satisfaction was observed for attributes such as shopping, connectivity, public utilities, availability of tourist information centre, promptness at the ticket window, availability of recreation and entertainment facilities. Likewise, researchers have observed that despiteworld-class restrooms available at the destination, they are not maintained, and the thieves have stolen all the latches, door hinges etc. due to unaccountability of the equipments.

Moreover, to enhance the visitor's experience under Ajanta andEllora Development Project, Visitors Orientation Centre was created at Ellora, the experts from the Department of Tourism Administration have prepared a visitors management plan for visitors movement at the caves sites. Still, unfortunately, tourists are not aware of its existence.

Harassment of the tourists by local vendors to sell their products forcefully was observed. These vendors also sell fake semi-precious stones in the name of original stones, and this leads to tourists carrying 
a wrong impression about the overall destination. Thus there is a dire need to station tourist police at the destination. Similarly, immoral activities such as consumption of alcoholic beverages in the caves, indecent behaviour among couples make obstacles for decent tourists to enter the caves. Hence it is suggested that ASI norms have to be strictly regulated, monitored and implemented at the cave site.

Further hotel accommodation indicated that staying was costly and somewhat unaffordable. Besides this recreational and entertainment facilities should be developed to enhance the tourist experience, which will lead to overall tourist satisfaction. Local stakeholders also need to be trained for better services.

Given global competitiveness in the tourism industry, destination managers, tourism officials and other tourist market companies should pay close attention to enhancing their existing services and facilities that were negatively evaluated in this research study. The research study also suggested that DMO's and the government should ensure local community satisfaction duringdevelopment of Destination loyalty. Thus Tourist satisfaction could be a possibility to boost revisit intention and employment levels.

Nevertheless, the present research does have some limitations about the small sample size; this small sample size might affecttheoverall generalization of the findings. There is an uneven footfall of tourists visiting Ellora caves due to seasonality which may have a significant impact on the outcomes.

\section{References}

Al Muala, A. (2017).The Impact Of Destination Image on Tourist Destination Loyalty in Jordan Tourism: The Mediating Effect of Perceived Trust. EPRA International Journal of Economic and Business Review,5(2), 117-124.

Gnanapala, W. A. (2015). Tourists perception and satisfaction: Implications for destination management. American Journal of Marketing Research, 1(1), 7-19.

D'Silva, B., \& D'Silva, S. (2008, May). Perception of tourists towards India as a preferred tourist destination- An empirical research. In Conference on Tourism in India-Challenges Ahead (Vol. 15, p. 17).

Bhat, M. A., \&Qadir, N. (2013). Tourist Satisfaction in Kashmir: An Empirical Assessment. Journal of Business Theory and Practice, 1(1), 150-166.

Bhat, S. A., \&Darzi, M. A. (2018). Antecedents of tourist loyalty to tourist destinations: A mediated-moderation study. International Journal of 
Tourism Cities, 4(2), 261-278.

Breiby, M. A., \& Slåtten, T. (2018). The role of aesthetic experiential qualities for tourist satisfaction and loyalty. International Journal of Culture, Tourism, and Hospitality Research, 12(1).

Bagri, S. C., \& Devkant, K. A. L. A. (2015). Tourists'satisfaction at Trijuginarayan, India: An importance-performance analysis. Advances in Hospitality and Tourism Research (AHTR), 3(2), 89-115.

Chi, C. G. Q. (2012). An examination of destination loyalty: Differences between first-time and repeat visitors. Journal of Hospitality and Tourism Research, 36(1), 3-24.

Dmitrovic, T., Cvelber, L., Kolar, T., Brencic, M., Ograjensek, I., \&Zabkar, V. (2009). Conceptualizing tourist satisfaction at the destination level. International Journal of Culture, Tourism and Hospitality Research, 3(2), 116126.

Gnanapala, A. (2016). Tourists Perception and Satisfaction : Implications for Destination Management. American Journal of Tourism Marketing Research, 1(1), 7-19.

Guntoro, B., \& Hui, T. K. (2013). Travel satisfaction and revisit intention of Chinese visitors: The case of Singapore. Advances in Hospitality and Leisure, 9, 29-47.

Gursoy, D., Chen, J. S., \& Chi, C. G. (2014). Theoretical examination of destination loyalty formation. International Journal of Contemporary Hospitality Management, 26(5), 809-827.

Hassan, M., \&Shahnewaz, M. (2014). Measuring Tourist Service Satisfaction at Destination: A Case Study of Cox's Bazar Sea Beach, Bangladesh. American Journal of Tourism, 3(1), 32-43.

Hikmah, Payangan, O. R., Munir, A. R., \&Jusni. (2018). The Effects of Tourism Products, Service Quality and Destination Uniqueness to the Satisfaction and Loyalty of Tourist in South Sulawesi. Scientific Research Journal, 6(1), 91-100.

Huh, J., Uysal, M., \&Mccleary, K. (2006). Cultural / Heritage Destinations : Tourist Satisfaction and Market Segmentation. Journal of Hospitality $\mathcal{E}$ Leisure Marketing, 14(3), 81-99.

Ibrahim, E. E., \& Gill, J. (2005). A positioning strategy for a tourist destination, based on analysis of customers' perceptions and satisfactions. Marketing Intelligence and Planning, 23(2), 172-188.

Jayaprakash, K., \& Mythili, B. (2017). Tourist Satisfaction Level on Destination Facilities In The Nilgiris. EPRA International Journal of Economic and Business Review, 5(9). 122-126

Kozak, M., \&Remmington, M. (2000). Tourist Satisfaction with Mallorca, Spain, as an Off-Season Holiday Destination. Journal of Travel Research, 38(3), 260-269.

Kumar, R. B., \& Dar, H. (2017). What makes Domestic tourists satisfied? An 
empirical study of Srinagar (Jammu and Kashmir). International Journal of Tourism and Travel, 10(1), 47-56.

M Philemon, J. R. (2015). Assessment of Tourists Perception And Satisfaction Of Tanzania Destination, 11(13).

Masarrat, G. (2012). Tourist's satisfaction towards tourism products and market: A case study of Uttaranchal. In Int. J Busi. Inf. Tech (Vol. 2, Issue 1).

Mohamad, M., Abdullah, A. R., \&Mokhlis, S. (2011). Examining the influence of service recovery satisfaction on destination loyalty: A structural equation modelling. Journal of Sustainable Development, 4(6), 3-11.

Mohamad, M., Ali, A. M., \&Izzati, G. N. A. (2011). A structural model of destination image, tourists'satisfaction and destination loyalty. International Journal of Business and Management Studies, 3(2), 167-177.

Mohamad, M., \&Izzati, G. N. A. (2014). The impact of tourist satisfaction on destination loyalty among European tourists visiting Malaysia. International Journal of Management Science, 2(8), 362-371.

Naidoo, P., Ramseook Munhurrun, P., \& Ladsawut, J. (2010). Tourist satisfaction with Mauritius as a holiday destination. Global Journal of Business Research, 4(2), 113-123.

Nowacki, M. (2013). The determinants of satisfaction of tourist attractions'visitors. Active.

Oppermann, M. (2000). Tourism Destination Loyalty. Journal Of Travel Research.

Rajesh, R. (2013). Impact of tourist perceptions, destination image and tourist satisfaction on destination loyalty: a conceptual model. PASOS.Revista de Turismo y Patrimonio Cultural, 11(3), 67-78.

Ragde, R. (2014a). Lecture. In R. S. M. Ragde (Ed.), Workshop on Prosperity through Tourism, Tourism Awareness Campaign Training Programme for Destination Community.

Ragde, R. (2014b). No Title. In R. Ragde (Ed.), Regional Level Tourist Guides refresher course. DTA, BAMU.

Rahman, T. H. M., \&Shil, R. S. (2012). Measuring service satisfaction of young tourists: a case study of Lawachara national park, Bangladesh. Anatolia, 32(2), 196-206.

Shirazi, F. M., \&Som, A. P. M. (2013). Relationship marketing and destination loyalty: Evidence from Penang,Malaysia. International Journal of Management and Marketing Research, 6(1), 95-106.

Somaskanthan, M., \&Rosmalina, A. R. (2016). Determining the relationship of tourist satisfaction and loyalty. Journal of Advanced Research in Social and Behavioural Sciences, 2(1), 93-101.

Tan, C.-H., Chong, X.-W., \& Vinayan, G. (2017). Perceived quality of visit and foreign tourists'satisfaction in Malaysia. International Journal of Management and Applied Science,3(2), 61-65.

Valle, P. O. D., Silva, J. a., Mendes, J., \& Guerreiro, M. (2006). Tourist 
satisfaction and destination loyalty intention : A structural and categorical analysis. International Journal of Business Science and Applied Management, 1(1), 25-44

Wang, X., Zhang, J., Gu, C., \& Zhen, F. (2009). Examining antecedents and consequences of tourist satisfaction: A structural modelling approach. Tsinghua Science \& Technology, 14(3), 397-406.

Wu, S., \& Zheng, Y. (2014). The Influence of Tourism Image and Activities Appeal on Tourist Loyalty - A Study of Tainan City in Taiwan.Journal of Management and Strategy, 5(4), 121-135.

Yoon, Y., \&Usyal, M. (2005). An examination of the effects of motivational and satisfaction on destination loyalty : a structural model. Tourism Management, 26, 45-56.

Zoghbi-Manrique-de-Lara, P., \& Guerra-Báez, R. M. (2016). Fairness in the local movements of tourists within a destination: justice perceptions, bus services, and destination loyalty. International Journal of Culture, Tourism, and Hospitality Research, 10(3), 323-339. 